\title{
Pengaruh Penambahan Indigofera zollingeriana dalam Stock Solution terhadap Motilitas dan Abnormalitas Spermatozoa Kambing Peranakan Etawa (PE)
}

\author{
Effect Additions of Indigofera zollingeriana in Stock Solution to Motility and Abnormality the \\ Semen of Peranakan Etawa Goat
}

\author{
A. W. Hastuti, D. Samsudewa, dan E. T. Setiatin \\ Fakultas Peternakan dan Pertanian Universitas Diponegoro \\ Kompl. drh. R. Soejono Koesoemowardojo, Tembalang Semarang (50275) \\ Corresponding email: widiannisa9@gmail.com
}

\begin{abstract}
The aims of the research were to examine with Indigofera zollingeriana in stock solution at different levels of motility and abnormality the spermatozoa of PE goat. The research used disselection quality test of semen by Balai Inseminasi Buatan (BIB) of Sidomulyo Ungaran that the motility was $<70 \%$. The dilution method of semen used Stock Solution with $0 \%, 1 \%, 2 \%$ and 3\% of Indigofera. The analyzed data used the normality test Shapiro-Wilk then Kruskal Wallis test analysis and Pearson correlation test were conducted to determine the relation of motility and abnormality the goat spermatozoa. The results of motility and abnormality spermatozoa were no significant. Treatment I1 with $1 \%$ Indigofera showed the highest motility (39.8\%) and lower abnormality $(22.52 \%)$. There was a relation between the motility with the abnormality, which was negatively correlated that was 0,224 . In conclusion, addition of $3 \%$ Indigofera in stock solution was able to endure motility and spermatozoa abnormality.
\end{abstract}

Key words : semen, motility, abnormality, Indigofera, dilution.

\begin{abstract}
ABSTRAK
Penelitian ini bertujuan untuk mengkaji pengaruh penambahan Indigofera zollingeriana dalam Stock Solution pada level penambahan yang berbeda terhadap motilitas dan abnormalitas spermatozoa kambing Peranakan Etawa (PE). Semen yang digunakan adalah semen afkir tidak lolos uji kualitas semen segar oleh Balai Inseminasi Buatan (BIB) Sidomulyo Ungaran yang memiliki motilitas $<70 \%$. Pengenceran semen menggunakan bahan pengencer stock solution dengan penambahan Indigofera 0\%, 1\%, 2\% dan 3\%. Data yang diperoleh dianalisis menggunakan analisis uji normalitas Shapiro Wilk dilanjutkan dengan analisis uji Kruskal Wallis dan dilakukan uji korelasi Pearson untuk mengetahui hubungan antara motilitas dan abnormalitas. Hasil analisis menunjukkan tidak ada perbedaan yang nyata $(\mathrm{H}$-hit $>0,05)$ antar perlakuan terhadap motilitas dan abnormalitas. Rataan motilitas tertinggi dan rataan abnormalitas terkecil pada perlakuan I1 yaitu sebesar $39,8 \%$ untuk motilitas dan 22,52\% untuk abnormalitas. Uji korelasi Pearson menunjukkan tidak ada korelasi bolak balik $(\rho>0,05)$ antara motilitas dan abnormalitas. Nilai korelasi sebesar $-0,224$ yang berarti hubungan antara motilitas dan abnormalitas adalah berlawanan arah. Artinya, apabila nilai motilitas tinggi maka nilai abnormalitas adalah rendah (kecil). Kesimpulan penelitian ini adalah penambahan Indigofera hingga level $3 \%$ dalam stock solution dapat mempertahankan motilitas dan abnormalitas spermatozoa.
\end{abstract}

Kata kunci : semen, motilitas, abnormalitas, Indigofera, pengenceran.

\section{PENDAHULUAN}

Perkawinan buatan saat ini mulai banyak digunakan dengan harapan keturunan yang dihasilkan akan memiliki produktivitas yang tinggi. Keberhasilan inseminasi buatan (IB) dapat dipengaruhi oleh beberapa faktor, diantaranya yaitu faktor peternak, ternak tersebut, inseminator dan kualitas semen (Susilawati, 2011). Kualitas semen beku untuk IB setidaknya memenuhi standar Post Thawing Motility (PTM) sebesar
40\% (Standar Nasional Indonesia, 2014). Untuk mencapai angka PTM sesuai standar, dilakukan perlakuan untuk mempertahankan angka motilitas spermatozoa dengan melalui proses pengenceran semen.

Berbagai bahan pengencer banyak digunakan dalam proses pembuatan semen beku, seperti Andromed ${ }^{\circledR}$ dan bahan pengencer dengan bahan dasar tris seperti tris aminomethan dan tris kuning telur. Bahan pengencer tersebut digunakan untuk melindungi spermatozoa dari 
cold shock ketika proses pendinginan, dimana terdapat kandungan bahan-bahan kimia selain bahan utama seperti kuning telur dan lesitin kedelai (Suharyati dan Hartono, 2011). Bahan yang terkandung dalam pengencer harus memenuhi syarat seperti, menambah volume semen, dapat menjadi sumber nutrisi bagi spermatozoa, mempertahankan tekanan osmosis, dapat bertindak sebagai buffer, dapat bertindak sebagai antibiotik dan tidak bersifat toksik (Susilawati, 2011). Tolok ukur keberhasilan bahan pengencer yaitu dapat dilihat dari tingkat motilitas dan abnormalitas spermatozoa setelah pemberian bahan pengencer. Motilitas yang baik ditandai dengan banyaknya gerak spermatozoa yang bergerak progresif maju ke depan dibanding non-progresif motility dan immotility yang teramati pada pengujian.

Pengencer buatan atau Stock Solution tersebut akan menjadi lebih optimal ketika dilakukan penambahan ekstrak bahan alami baik dari tumbuhan maupun buah-buahan. Rophi et al. (2018) menjelaskan bahwa penambahan bahan alami yang mengandung flavonoid, alkaloid, saponin dan triterpenoid sebagai antioksidan mampu membatasi proses peroksidasi lipid, sehingga menurunkan tingkat abnormalitas pada spermatozoa ketika penambahan bahan pengencer.

Bahan tambahan alami yang dapat ditambahkan dalam bahan pengnecr dengan protein kasar (PK) yang tinggi, salah satunya adalah jenis leguminosa. Dewasa ini, penggunaan tarum (Indigofera zollingeriana) banyak digunakan untuk pakan ternak terkhusus pada kambing jantan. Banyak pendapat menyebutkan, penggunaan tarum sebagai pakan dapat meningkatkan kulitas semen kambing. Berdasarkan hal tersebut, penambahan tarum sebagai bahan alami dalam pengencer dengan memperhatikan syarat-syarat bahan pengencer. Kandungan nutrisi pada tarum yang mengandung protein kasar (PK) sebesar 27,9\%, serat kasar (SK) sebesar 15, Ca sebesar 0,22\% dan P sebesar 0,18\% (Ratih et al., 2016) kandungan $\mathrm{Ca}$ dan $\mathrm{P}$ pada tarum menurut Herdiawan dan Krisman (2014) lebih tinggi 7,7\% dibanding leguminosa yang lain. Kandungan $\mathrm{Ca}$ dan $\mathrm{P}$ ini apabila ada dalam bahan pengencer dapat memperkaya kandungan buffer dalam pengencer. Tarum mengandung fenol sebesar $0,22 \%$ dan flavanoid sebesar $0,14 \%$ yang dapat memperkaya kandungan antibiotik dalam pengencer apabila digunakan dalam bahan pengencer.
Berkaitan dengan uraian tersebut, maka dilakukan penelitian mengenai penambahan bahan alami dalam stock solution pengencer yang bertujuan untuk mengkaji pengaruh penambahan tarum (Indigofera zollingeriana) dalam stock solution pada level penambahan yang berbeda terhadap motilitas dan abnormalitas spermatozoa pada semen kambing. Manfaat terhadap penelitian adalah dapat diperoleh informasi mengenai penambahan tarum (Indigofera zollingeriana) yang optimal dalam stock solution yang dapat mempertahankan motilitas spermatozoa dan menghambat peningkatan abnormalitas spermatozoa pada semen kambing.

\section{MATERI DAN METODE}

Materi yang digunakan dalam penelitian yaitu semen segar dari 6 ekor kambing Peranakan Ettawa dengan persentase motilitas spermatozoa $<70 \%$ pada uji kualitas semen segar di BIB Sidomulyo Ungaran yang tidak lolos seleksi. Bahan stock solution yang digunakan disajikan dalam Tabel 1. Indigofera zollingeriana yang ditambahkan berupa larutan hasil sentrifus yang diambil supernatan dan berasal dari kebun tanaman BIB Sidomulyo Ungaran. Keseluruhan pembuatan larutan pengencer dilakukan di Fakultas Peternakan dan Pertanian, dan kegiatan penelitian dilakukan di Laboratorium BIB Sidomulyo Ungaran. Penelitian ini dilaksanakan dengan tiga tahap yaitu tahap persiapan, tahap perlakuan dan tahap pengambilan data. Data motilitas dan abnormalitas yang telah diperoleh dilakukan uji normalitas data menggunakan uji normalitas Shapiro-Wilk, dilanjutkan pengujian statistik non parametrik menggunakan uji Kruskal Wallis. Pemilihan uji statistik Kruskal Wallis didasarkan pada tidak terpenuhinya asumsi pada uji One Way Annova pada data yang diperoleh dari hasil penelitian. Data penelitian dilakukan uji Korelasi Pearson untuk mengetahui hubungan antara variabel x (motilitas) dengan variabel y (abnormalitas). Keseluruhan uji dilakukan dengan bantuan program analisis statistik Statistical Package for the Social Sciences (SPSS) versi 23.0.

Bahan pengencer yang telah dihitung tiap semen segar kemudian dibagi menjadi empat dan dimasukkan dalam tabung reaksi. Tabung diberikan label I0, I1, I2 dan I3. Masing-masing tabung diberikan perlakuan sesuai label dengan supernatan larutan Indigofera yang terdiri dari : 
I0 : Larutan Indigofera 0\% dalam larutan Stock Solution.

I1 : Larutan Indigofera 1\% dalam larutan Stock Solution.

I2 : Larutan Indigofera 2\% dalam larutan Stock Solution.

I3 : Larutan Indigofera 3\% dalam larutan Stock Solution.

Rancangan yang digunakan yaitu dengan menggunakan Rancangan Acak Lengkap (RAL) dengan 4 perlakuan dan 6 ulangan. Data motilitas dan abnormalitas yang telah diperoleh dilakukan uji normalitas data menggunakan uji normalitas Shapiro-Wilk dan dilanjutkan uji Kruskal Wallis. Data penelitian dilakukan uji Korelasi Pearson untuk mengetahui hubungan antara variabel $\mathrm{x}$ (motilitas) dengan variabel y (abnormalitas).

Tabel 1. Bahan stock solution

\begin{tabular}{lc}
\hline \multicolumn{1}{c}{ Bahan } & Jumlah $(\mathrm{gr} / 100 \mathrm{ml})$ \\
\hline $\mathrm{NaCl}$ & 0,6546 \\
$\mathrm{KCl}$ & 0,0300 \\
$\mathrm{NaH}_{2} \mathrm{PO}_{4} 6 \mathrm{H}_{2} \mathrm{O}$ & 0,0114 \\
$\mathrm{MgCl}_{2} 2 \mathrm{H}_{2} \mathrm{O}$ & 0,0106 \\
$\mathrm{CaCl}_{2} 2 \mathrm{H}_{2} \mathrm{O}$ & 0,0331 \\
$\mathrm{NaHCO}_{3}$ & 0,3108 \\
Penicillin & 0,1000 \\
Glukosa & 0,2756 \\
Natrium Piruvat & 0,0138 \\
\hline
\end{tabular}

\section{HASIL DAN PEMBAHASAN}

Penelitian ini akan mensajikan hasil evaluasi semen segar sebelum pengenceran, motilitas spermatozoa setelah pengenceran, abnormalitas spermatozoa setelah pengenceran dan hubungan antara motilitas dan abnormalitas.

\section{Evaluasi Semen Segar Kambing}

Rataan pengujian yang dilakukan dalam evaluasi semen segar kambing sebelum diberikan perlakuan pada Tabel 2. Hasil evaluasi semen kambing afkir sesuai persyaratan semen segar lolos seleksi oleh Balai Inseminasi Buatan, Ungaran menunjukkan rata-rata volume ejakulat kambing yaitu sebesar 1,72 $\pm 0,82 \mathrm{ml}$. Banyaknya ejakulat ini dalam kisaran normal setelah dibandingkan dengan hasil penelitian Rophi et al. (2018) yaitu pada volume semen segar kambing akan diperoleh volume sebanyak 1 sampai $2 \mathrm{ml}$ dengan rata-rata volume $1,87 \pm$ $0,24 \mathrm{ml}$. Frekuensi warna semen segar kambing yang sering muncul adalah berwarna krem yang berada dalam kisaran normal warna semen segar kambing. Sesuai dengan hasil penelitian Ariantie et al. (2014) bahwa warna semen segar kambing hasil penampungan biasanya berwarna krem.

Konsistensi semen kambing memiliki rataan kental dan hal tersebut menunjukkan bahwa semen kambing yang digunakan dalam kisaran normal. Hal ini sesuai dengan pendapat Ariantie et al. (2014) bahwa kisaran normal konsistensi semen kambing apabila memiliki konsistensi kental.

Tabel 2. Rataan evaluasi semen segar kambing

\begin{tabular}{ll}
\hline Karakteristik semen & Rataan \\
\hline Volume $(\mathrm{ml})$ & $1,72 \pm 0,82$ \\
Warna & Putih kekuningan \\
Konistensi & Kental \\
$\mathrm{pH}$ & $6,9 \pm 0,11$ \\
Konsentrasi $\left(\times 10^{6} \mathrm{sel} / \mathrm{ml}\right)$ & $2.665,5 \pm 893,48$ \\
Gerak massa & +1 \\
Motilitas $(\%)$ & $41,67,11,69$ \\
Abnormalitas $(\%)$ & $16.30 \pm 5,58$
\end{tabular}

Keterangan : +1 (kurang baik)

Hasil pengujian konsistensi menjadi salah satu tolok ukur besar konsentrasi semen. Hal ini sesuai dengan pendapat Susilawati (2011) bahwa semakin kental konsistensi maka konsentrasi yang dimiliki semakin besar. Pengujian ph menunjukkan rataan sebesar 6,9 \pm 0,11 dimana hasil ini dalam kisaran normal jika dibandingkan dengan hasil penelitian Ihsan (2013) yaitu sebesar $7 \pm 0,00$.

Hasil pengujian konsentrasi menunjukkan bahwa rata-rata konsentrasi semen kambing dalam penelitian sebesar 2.665,50 \pm $893,48 \times 10^{6} \mathrm{sel} / \mathrm{ml}$. Nilai konsentrasi ini dalam kisaran normal sebagai semen segar sesuai dengan pendapat Susilawati (2011) dalam bukunya menjelaskan bahwa konsentrasi semen domba dan kambing ada dalam kisaran 2.000 3.000 juta. Berdasarkan pengamatan gerak massa, motilitas dan abnormalitas menunjukkan rataan yang rendah yaitu masing-masing bernilai $(+1), 41,67 \pm 11,69 \%$ dan $16,36 \pm 5,58 \%$. Hasil ini menunjukkan bahwa pergerakan yang dimiliki spermatozoa selama kondisi segar adalah lambat, sehingga tidak dimungkinkan untuk diproses menjadi semen beku. Hal ini sesuai dengan pendapat Susilawati (2011) bahwa skor gerak massa (+1) menunjukkan pergerakan yang ada bersifat individu dan bernilai kurang baik apabila diproses lebih lanjut menjadi semen beku. Besar rataan motilitas yang diperoleh dapat dikatakan dibawah normal sebesar $41,67 \%$, sehingga tidak 
dapat diproduksi menjadi semen beku dibandingkan dengan pendapat Susilawati (2011) yang menyatakan kenormalan motilitas individu yaitu berkisar $70-90 \%$. Namun, hasil pengamatan abnormalitas menunjukkan hasil dalam kisaran normal sesuai pendapat Susilawati (2011) bahwa tingkat abnormalitas yang baik apabila berada di bawah angka $20 \%$.

\section{Motilitas}

Hasil analisis uji Kruskal Wallis yang telah dilakukan tidak ada perbedaan yang nyata $(\mathrm{H}>0,05)$ antar perlakuan yang diberikan. Rataan hasil pengamatan motilitas dengan perlakuan penambahan Indigofera dengan taraf yang berbeda disajikan pada Tabel 3. Ilustrasi 1. menunjukkan pada perlakuan I1 memiliki tingkat motilitas yang lebih tinggi sebesar 39,8\% dibanding dengan perlakuan kontrol (I0) sebesar $39,25 \%$. Hal ini menunjukkan penambahan Indigofera pada taraf $1 \%$ dapat mempertahankan motilitas spermatozoa. Persentase motilitas yang rendah dapat diakibatkan terganggunya fisiologis membran plasma akan mengalami akibat peroksidasi lipid dan adanya radikal bebas dalam bentuk Reactive Oxygen Species (ROS). Membran spermatozoa terdiri dari protein dan lipid sebagai penyusun membran. Menurut Romadhoni et al. (2014) menjelaskan bahwa bagian membran plasma spermatozoa terdiri dari $40 \%$ lipid (65\% fosfoipid, $25 \%$ kolesterol dan $10 \%$ lipid lainnya) dan $60 \%$ protein. Kandungan Indigofera dalam stock solution berhasil membantu mempertahankan motilitas spermatozoa agar tidak mengalami penurunan yang drastis. Pemberian Indigofera dalam taraf yang lebih tinggi menunjukkan penurunan motilitas lebih banyak pada perlakuan I2 sebesar $38,42 \%$ dan pada perlakuan I3 semakin menurun sebesar $37,47 \%$. Zat dalam bahan pengencer yang dapat memberikan fungsi tersebut adalah zat antioksidan. Bebas et al. (2016) menyebutkan bahwa antioksidan dalam bahan pengencer dapat memutus rantai peroksidasi lipid pada membran plasma sel, sehingga kerusakan pada membran dapat terhambat dan intregitas membran dapat terjaga. Indigofera yang ditambahkan dalam Stock Solution mengandung kandungan nutrisi yang dimungkinkan membantu mencegah dan menahan peristiwa peroksidasi lipid. Radikal bebas yang bereaksi dengan oksigen akan menghasilkan senyawa peroksidasi aktif. Tidak adanya antioksidan dalam asam lemak, akan terbentuk reaksi antara peroksidasi dengan ikatan rangkap lemak.

Tabel 3. Motilitas semen setelah pengenceran

\begin{tabular}{ccccc}
\hline \multirow{2}{*}{ Ulangan } & \multicolumn{4}{c}{ Motilitas Semen } \\
\cline { 2 - 5 } & I0 & I1 & I2 & I3 \\
\hline \multirow{2}{*}{1} & ------------- & \% & -------------- \\
2 & 43,3 & 59,3 & 57,3 & 53 \\
3 & 39 & 45,6 & 46 & 46 \\
4 & 38,6 & 39,6 & 38,6 & 38 \\
5 & 28 & 28,3 & 37 & 36,6 \\
6 & 28 & 27 & 25,6 & 26,6 \\
Rataan & 39,25 & 39,80 & 38,42 & 37,47 \\
\hline
\end{tabular}

Namun, apabila terdapat antioksidan maka peroksidasi tersebut tidak langsung bereaksi dengan ikatan rangkap lemak, sehingga peroksidasi aktif dapat dihambat. Peroksidasi yang terhambat maka akan mempengaruhi kondisi membran plasma menjadi lebih utuh dan metabolisme menjadi lebih baik. Kandungan antioksidan dalam Indigofera yang ditambahkan pada stock solution mampu membantu mempertahankan motilitas spermatozoa agar tidak mengalami penurunan yang drastis. Adanya radikal bebas dalam bentuk ROS juga dapat merusak membran sel dan lebih khususnya pada mitokondria. Mitokondria dengan kondisi membran yang rusak, akan terganggu fungsi fisiologis maupun biokimiawinya. Selain itu, pergerakan sperma akan ikut terhambat karena letak mitokondria yang ada pada ekor sperma. pergerakan ekor yang terhambat maka juga menyebabkan persentase motilitas menjadi menurun.

\section{Abnormalitas}

Hasil analisis ragam menunjukkan bahwa tidak ada perbedaan yang nyata $(\mathrm{H}>0,05)$ antar perlakuan terhadap pengujian abnormalitas dengan penambahan berbagai taraf pemberian Indigofera dalam stock solution. Rataan abnormalitas spermatozoa disajikan pada Tabel 4. yang menunjukkan adanya kenaikan abnormalitas spermatozoa setelah pengenceran.

Kenaikan abnormalitas disebabkan adanya kerusakan membran akibat preparasi proses pengenceran. Bentuk abnormalitas dengan pengencer stock solution yang ditemui pada Gambar 1. adalah ekor melingkar dan ekor terputus. Toelihere (1981) menjelaskan bahwa morfologi spermatozoa yang abnormal ketika pengamatan dapat berasal dari proses pembentukan dalam tubulus seminiferi dan 
kelainan spermatozoa ketika meninggalkan epididimis hingga diejakulasikan.

Tabel 4. Abnormalitas semen setelah pengenceran

\begin{tabular}{ccccc}
\hline \multirow{2}{*}{ Ulangan } & \multicolumn{4}{c}{ Abnormalitas Semen } \\
\cline { 2 - 5 } & I0 & I1 & I2 & I3 \\
\hline & ------------------ & ---------------------- \\
1 & 17,7 & 16,12 & 19,4 & 12,79 \\
2 & 43,88 & 35,32 & 41,22 & 42,35 \\
3 & 17,31 & 13,13 & 14,23 & 18,42 \\
4 & 23,82 & 16,07 & 17,37 & 24,37 \\
5 & 22,95 & 20,65 & 24,92 & 17,39 \\
6 & 37,09 & 33,85 & 39,83 & 33,13 \\
Rataan & 27,13 & 22,52 & 26,16 & 24,74 \\
\hline
\end{tabular}

Kelainan atau bentuk abnormal spermatozoa dapat bertambah dengan adanya preservasi. Namun, rentang kenaikan abnormalitas spermatozoa tidak terlalu drastis yang dimungkinkan sebagai akibat kandungan antioksidan dalam Indigofera dapat membantu menghambat peningkatan kadar fosfolipid pada membran spermatozoa, sehingga Reactive Oxygen Species (ROS) juga terhambat. Pendapat Romadhoni et al. (2014) menyebutkan bahwa Reactive Oxygen Species (ROS) pada semen memiliki kadar yang rendah apabila reaksi peroksidasi dengan fosfolipid yang ada pada lipid membran spermatozoa juga rendah, sehingga membran sperma tidak mengalami kerusakan yang merupakan salah satu faktor keabnormalan spermatozoa.

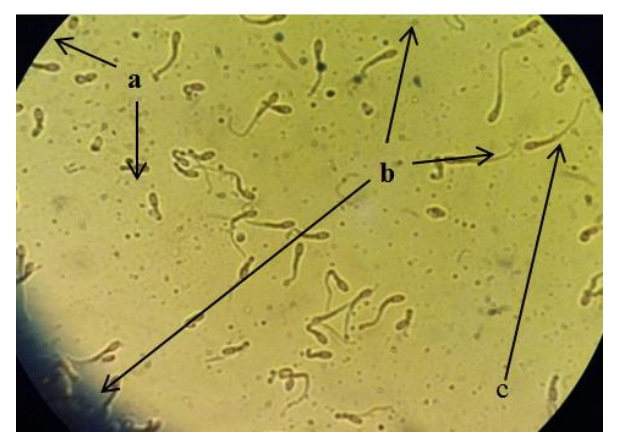

Gambar 1. Abnormalitas primer ekor melingkar (a); abnormalitas sekunder ekor terputus (b) dan spermatozoa normal (c).

Penambahan Indigofera dalam stock solution mampu menahan tingkat abnormalitas dibandingkan tanpa penambahan Indigofera oleh adanya kandungan antioksidan berupa fenol dan flavanoid. Antioksidan pada Indigofera akan memutus reaksi peroksidasi pada ikatan rantai lipid pada membran plasma, sehingga membran plasma dapat terlindungi dan abnormalitas dapat terhambat.

Artinya, abnormalitas primer yang terjadi sebelum semen diejakulasikan yang dimungkinkan akibat peroksidasi lipid dari dalam dapat dihambat kenaikannya agar tidak terjadi abnormalitas sekunder yang besar. Fungsi pengencer sebagai pelindung membran sel berasal dari kandungan protein yang ada di dalam pengencer. Menurut Ratih et al. (2016) tingginya kandungan PK sebesar 27,9\% yang terdapat dalam Indigofera dimungkinkan dapat dimanfaatkan sebagai tambahan protein untuk krioprotektan ekstraseluler pada semen kambing sehingga tingkat abnormalitas spermatozoa dapat dihambat.

Abnormalitas sekunder yang disajikan pada Gambar 1. diduga terjadi akibat proses ejakulasi dan preparasi. Preparasi yang mungkin mengakibatkan terjadinya abnormalitas sekunder yaitu pembuatan ulas preparat. Salim et al. (2012) menjelaskan bahwa abnormalitas sekunder yang terjadi seperti ekor putus atau kepala patah, diakibatkan adanya preparasi pembuatan ulas dan dimungkinkan akibat ejakulasi yang kurang sempurna sehingga ekor spermatozoa menjadi terputus.

\section{Hubungan antara Motilitas dan Abnormalitas}

Hubungan antara motilitas dan abnormalitas akibat penambahan Indigofera dalam stock solution dibuktikan dengan hasil analisis uji korelasi Pearson diketahui bahwa tidak ada hubungan bolak balik antara motilitas dan abnormalitas spermatozoa $(\rho>0,05)$. Nilai korelasi yang dihasilkan dari analisis uji adalah sebesar $-0,224$ yang berarti ada hubungan tidak searah antara motilitas dan abnormalitas spermatozoa.

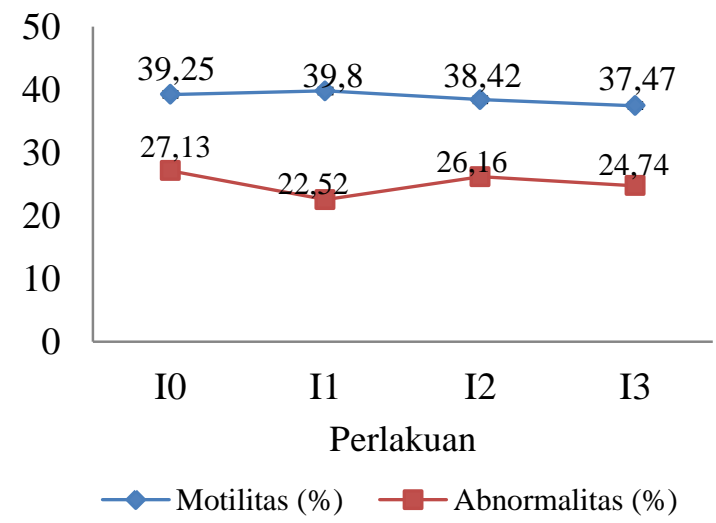

Gambar 2. Gambar motilitas dan abnormalitas 
Gambar 2. menunjukkan bahwa perlakuan I1 mampu mempertahankan motilitas lebih baik dan memiliki nilai abnormalitas paling rendah. Menurut pendapat Mas dan Prastiwi (2016) bahwa nilai korelasi $0,2-<0,4$ dalam angka positif atau negartif menunjukkan adanya hubungan yang rendah dari variabel-variabel yang diuji. Hubungan tidak searah antara motilitas dan abnormalitas dapat diartikan apabila persentase motilitas tinggi maka angka abnormalitas akan kecil / rendah. Rophi et al. (2018) menjelaskan bahwa nilai motilitas yang tinggi dan nilai abnormalitas lebih rendah menunjukkan kualitas spermatozoa masih dapat dipertahankan.

\section{KESIMPULAN}

Penambahan Indigofera hingga level penambahan 3\% mampu mempertahankan motilitas dan abnormalitas spermatozoa. Perlu adanya penelitian mengenai waktu pengamatan dengan level pemberian Indigofera yang berbeda terhadap motilitas dan abnormalitas semen kambing.

\section{DAFTAR PUSTAKA}

Ariantie, O. S., T. L. Yusuf, D. Sajuthi dan R. I Arifiantini. 2014. Kualitas semen cair kambing Peranakan Etawah dalam modifikasi pengencer tris denan trehalosa dan rafinosa. J. Veteriner. 15 (1) : $11-$ 22.

Bebas, W., G. L. Buyona dan M. K. Budiasa. 2016. Penambahan vitamin E pada pengencer BTS $\AA$ terhadap daya hidup dan motilitas spermatozoa babi Landrace pada penyimpanan $150 \mathrm{C}$. Buletin Veteriner Udayana. 8 (1): 1 - 7.

Herdiawan, I. dan R. Krisnan. 2014. Produktivitas dan pemanfaatan tanaman leguminosa pohon Indigofera zollingeriana pada lahan kering. Wartazoa. 24 (2) : $75-82$.

Ihsan, M. N. 2013. Pembekuan vitrifikasi semen kambing Boer dengan tingkat gliserol berbeda. J. Ternak Tropika. 14 (2) : 38 45.
Mas, I K. G. Y. dan W. D. Prastiwi. 2016. Biometrika Peternakan. Penerbit Media Inspirasi Semesta, Semarang.

Ratih, Y. W., P. B. Santosa dan E. Muryani. 2016. Pengaruh limbah industri batik menggunakan pewarna alami dari desa Wukirsari terhadap viabilitas bakteri tanah. J. Eksergi.13 (2) : 7 - 13.

Romadhoni, I., A. Rachmawati dan Suyadi. 2014. Kualitas semen sapi Madura setelah pengenceran dengan tris aminomethane kuning telur yang disuplementasi $\alpha$ tocopherol pada penyimpanan suhu ruang. J. Ilmu-Ilmu Peternakan. 24 (1) : $39-44$.

Rophi, A. H., S. Rahayu dan G. Ciptadi. 2018. The effect of Morinda citrifolia L. fruit extract supplemented to deluent tris-egg yolk toward the abnormality of goat's spermatozoa after freezing at $-80 \mathrm{oC}$. Journal of Experimental Life Science. 8 (3) : $145-152$.

Salim, M. A., T. Susilawati dan S. Wahyuningsih. 2012. Pengaruh metode thawing terhadap kualitas semen beku sapi Bali, sapi Madura dan sapi PO. Agripet. 12 (2): 14 - 19.

Standar Nasional Indonesia. 2014. Semen Beku bagian 3 Kambing dan Domba SNI 4869.3: 2014. Badan Standarisasi Nasional, Jakarta.

Suharyati, S. dan M. Hartono. 2011. Preservasi dan kriopreservasi semen sapi Limousin dalam berbagai bahan pengencer. J. Kedokteran Hewan. 5 (2) : 53 - 58.

Susilawati, T. 2011. Spermatologi. Universitas Brawijaya Press, Malang.

Toelihere, M. R. 1993. Inseminasi Buatan pada Ternak. Penerbit Angkasa, Bandung. 